\title{
Reports about Occurrence of Events with Effect on Aviation Safety
}

\author{
Vladimír Plos \\ Laboratory of aviation safety and security, \\ Department of air transport, Faculty of Transportation \\ Sciences, Czech technical university in Prague \\ Horská 3, Praha 2, 128 03, Czech Republic \\ e-mail: plosvlad@fd.cvut.cz
}

\author{
Peter Vittek \\ Laboratory of aviation safety and security, \\ Department of air transport, Faculty of Transportation \\ Sciences, Czech technical university in Prague \\ Horská 3, Praha 2, 128 03, Czech Republic \\ e-mail: vittek@fd.cvut.cz
}

\author{
Karel Jeřábek \\ Department of air transport \\ Faculty of Transportation Sciences, Czech technical university in Prague \\ Horská 3, Praha 2, 128 03, Czech Republic
}

\begin{abstract}
This article deals with a system, that is established to report the events with effect on safety. This system is based on requirements published in Annex 13 to the Chicago Convention and legislative foundations laid down in Regulation L13, Regulation of the European Parliament and of the Council (EU) No 376/2014, Decree No. 359/2006 Sb. and Act No. 49/1997 Sb. Standards and legislative rules precisely define the types of events that are subject of reporting and also define the structure and content of the reporting message. This content is consists mainly of the identification data about the airplane and crew, information about the route and a short description of the damage to the airplane. In the following, we discuss the possible use of such a system of mandatory reporting for the needs of safety indicators. Then there are proposals of changes in the content of the reporting message for the need of safety indicators. The present knowledge indicates that the use of all opportunities provided by the law for the reporting of events can lead to a creating of sufficient basis for safety indicators.
\end{abstract}

Keywords-safety; L-13; Regulation of the European Parliament and of the Council (EU) No 376/2014, safety, incident, serious incident, air accident, mandatory reporting system, voluntary reporting system

\section{INTRODUCTION}

The reporting of incidents and accidents is based on history - since the beginning of air transport it was needed to investigate aviation incidents and accidents in order to take safety measures to prevent the recurrence of such events, or at least mitigate the consequences. Over time, the states established authorities dealing with the investigation of aviation accidents and there was also an obligation to report the occurrence of events that would affect the safe conduct of air operations. In the Czech Republic we have special institution -
Air Accident Investigation Institute (Czech abbreviation is UZPLN). The establishment of this Institute is defined by Act No. 258/2002, amending the Civil Aviation Act 49/1997, to meet the requirements formulated by the European Community Council Directive 94/56/EC of 21 November 1994. Additionally, we deal with a situation that is common in the Czech Republic.

The reporting system of events with an impact on safety is constantly evolving and it is necessary to adapt it to current needs for obtaining the necessary data. The main purpose of the supervision of aviation safety is the analysis, definition of corrective actions and their implementation.

\section{CURRENT STATUS OF REPORTS TO ÚZPLN}

At present, the reporting system is established by regulation L13, where a mandatory reporting is introduced in cases specified by regulation EC 42/2003. Czech legislation defines the requirements of the above-mentioned regulations in Decree $359 / 2006$. In the case of occurrence of such events, there is need to report it in the shortest time in form, which is specified in L13 Appendix N. This appendix describes a number of mandatory items that are designed to identify exactly what happened, who is involved and the circumstances of the case. These items are:

- Identification of event

- Aircraft identification, identification of the owner

- Identification of the crew

- Date and time of event

- Departure/arrival airport

- Position of the aircraft 
- Data about injury/death of crew/passengers, or number of victims out of plane

- Description and extent of damage

- Characteristics of the incident location and description of the approach

- Presence of dangerous goods

This structure of the report is sufficient as an initial information about an accident/incident and provides investigators useful information about the location and nature of the event. However, a detailed description of the accident, can only be inserted into the column titled "Description and extent of damage", where the announcer can describe the damage to the aircraft depending on the events that preceded the damage. But this "extended" description may not occur in each announcement. In many cases there is only a stark description of damage to the airplane, which was established on the basis of impact, fire, etc.

Decree 359/2006 directly specifies the cases in which notification has to be done. These situations are divided into several categories:

- Flight Operations

- Technical issues on aircraft

- Matters relating to maintenance and repair work on the aircraft

- ANS activities

- Ground staff activities

For all these categories it is necessary to report the types of events such as an accident, serious incident, incident and also the type of events called "occurrence". This is an event that does not fall into the category of incidents or accidents, but its potential may lead to the realization of the event, which will already fall within the above categories. Reporting of this type of event is directly proportional to the reporting culture in company. In terms of a properly functioning SMS with well-developed safety and reporting culture, operational staff does not have a problem to report these events. In conditions where for any misconduct threatens only repression and where is no positive way for reporting support, it is very difficult to obtain information on this type of event.

In the regulation is further mentioned that all of the information from the investigation of aviation accidents has to be archived in a database managed by the authority for the investigation of air accidents. Information about the investigation of incidents and serious incidents are recommended to archive. This archive is maintained to the possibility of sharing safety data and thus to spread awareness about the events, their causes, etc.

\section{EVALUATION OF MANDATORY REPORTING SYSTEM}

The above legislative provisions are related to the system of mandatory reporting where the participant is obliged to report the event to the relevant authorities. From the reports to these agencies should be immediately clear what type of event it is, the severity of the event, how many aircraft were involved in events, etc. To the initial entry would be appropriate to add a column with the brief description of the event. Thanks to this, it would be easier to classify an event in one of the specific categories of prepared safety indicators. This is important for monitoring of safety indicators while the issue of final report may take longer time and the necessary data might be missing in the surveillance system even if the event has already happened.

The occurrence of the events referred to in EU Regulation $42 / 2003$ as "occurrences" are almost not reported in the conditions of the Czech Republic. In this we see a lot of room for improvement while these messages are for the safety information system most valuable due to their potential. For this type of message it is possible to easily define the systems of safety indicators. These indicators would focus on one of the lowest levels of occurrence of operational deviations.

\section{VOLUNTARY REPORTING SYSTEM}

One of the goals of improving safety and raise awareness about safe processes in aviation is based on the voluntary reporting system. This system is based on the free will of the announcer to report an event that is not completely in accordance with good working practices, but it did not mean the realization of a hazardous event. The findings of these reports can be used to prevent such events with little meaning. However, in the theory of safety, Reason model, etc., it is known that these small events, seemingly without compromising on safety, are actually triggers to the realization of serious events. Using a system of voluntary reporting and its promotion among operating staff, it is possible to increase the percentage of reported events and a thorough analysis of received notifications can be adopted properly targeted safety measures. Voluntary reporting system, however, cannot become a tool for finding the culprits. The anonymity of the reporter must be guaranteed.

By the voluntary reporting system it can be expanded mainly a series of reports on "occurrences". Given their nature, these reports will be mostly obtained only by a system of voluntary reporting.

With voluntary reporting systems and appropriate responses to stimuli derived therefrom, in the organization expands awareness of safety - the safety culture. With this approach, we can then achieve an increase in the percentage of reportable events since the operating personnel begin to perceive the reporting rather than a punishment for them personally, as an aid in the prevention of others from the realization of hazardous events.

\section{EXAMPLES OF REPORTING SYSTEMS}

Currently in the Czech Republic, there are working several reporting systems, whether on national basis or internally based in organizations. As an example we can mention the national project on the CAA website. Here's possibility to report any initiative connected with its activities, i.e. including complaints about aircraft operations. This system is not anonymous and 
directly requires identification of the complainant. Also the name of this system containing the word "complaint" is not properly chosen. Rather, as a system for voluntary reporting of its own mistakes appears to be a system for reporting errors of other airspace users.

Another example of reporting system is a web application on Prague Airport website. This system by its nature meets the requirements for anonymity and the basic structure of the form primarily interested in the time, date, location and event description. Contact information of the announcer is optional.

The last mentioned example is the system of ANSP Czech Republic. This system allows data entering again about the events that operational staff noted in their workplace and is considered as a deviation from standard procedures. This system is based on the fact that voluntary reporting of events is better for the operating staff than the subsequent investigation at the initiative of the automatic evaluation system. The ANSP Company has also very effective feedback system, where each stimulus is investigated and corrective measures are taken immediately in practice.

\section{VOLUNTARY REPORTING SYSTEM REQUIREMENTS}

As an ÚZPLN mandatory reporting system has its firm structure and content requirements, a system of voluntary reporting in organizations or on the web site of the national regulator should have a unified form to make it easy to navigate through the entries and effectively evaluated them. This will be achieved only by clear structure, definition of each field, decision menus, etc. For an employee who fills out the appropriate forms, it is easier to navigate through the system of checkboxes or few words description fields than when the announcer has to write a long text about the event. Such texts are often confusing due to a lack of consistency and it is difficult "filter out" the relevant information. The aim of making the reporting form should therefore be a clear structure with emphasis on the requirement of brief and accurate information. From the structure of reporting form must be immediately clear what data we want to obtain from the announcer.

\section{STORAGE AND USING THE DATA}

The data obtained from the mandatory and voluntary reporting systems should be stored in databases of safety events, and then these data should be analyzed in the context of determining the level of safety. One example is the ECCAIRS that works within the Member States of EASA and in which you can find incidents and accidents that were reported to the supervising authorities of the Member States. This database can store data on individual incidents/accidents by the exact taxonomy. Currently, we use several taxonomies - ADREP taxonomy (ECCAIRS), Heide (EUROCONTROL) or ICAO general taxonomy. These taxonomies are comparable and it allows entries to be unified, it means also comparable. Thus unified records can then be easily compared, searched for individual events using predefined keywords, etc.
Using a variety of preset filters corresponding to the exact needs of safety indicators defined both within the organization and within the State safety program of civil aviation, we can quickly and efficiently obtain safety data and we can focus corrective measures specifically on the problem area with increasing indicator.

The following figure shows the ideal life cycle of reporting events. It begins by reporting actual events and ends with the final report and subsequent feedback to reporting events. In the case of voluntary reporting, it is a support to voluntary reporting in the form of a non-punitive assessment and subsequent adoption of targeted safety measures.

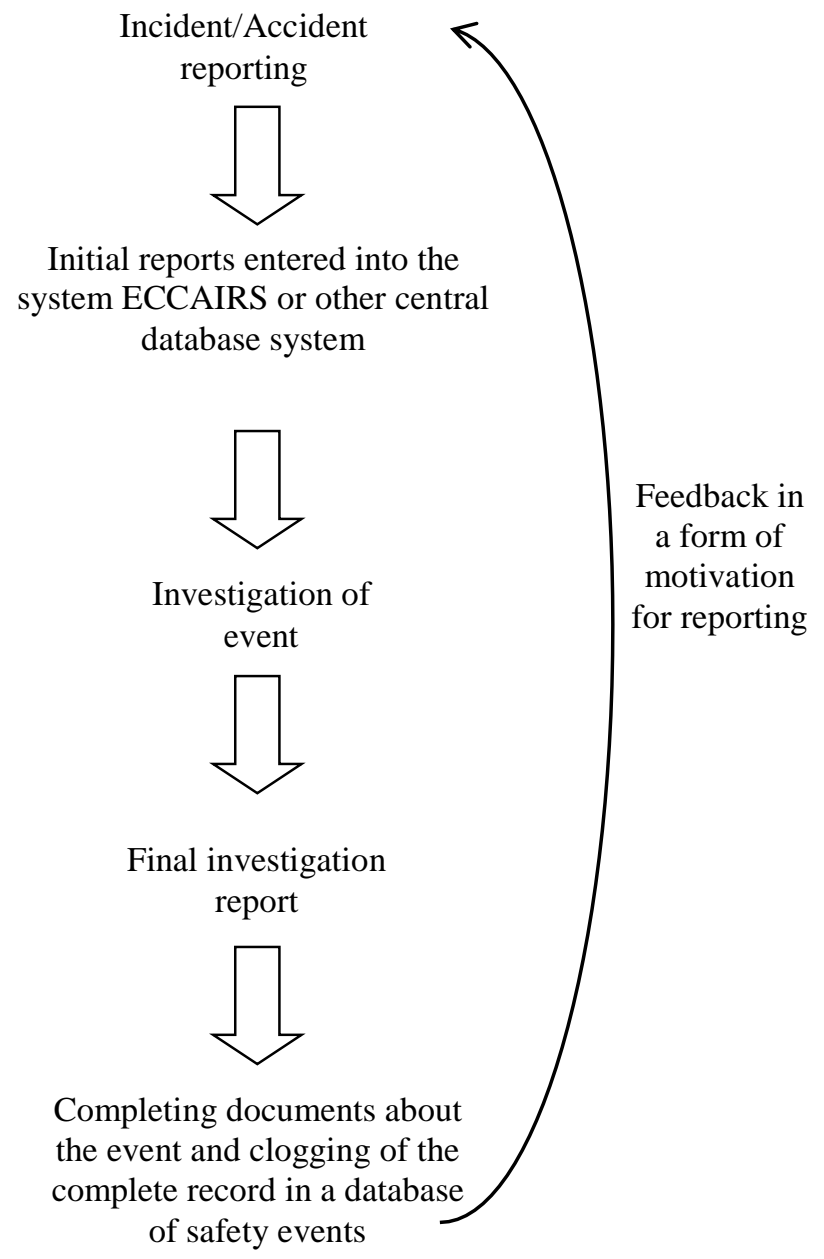

Fig.1 Ideal life cycle of reported event data

\section{PROPOSAL TO SUPPLEMENT THE REPORTING SYSTEM}

The reporting of incidents in the Czech Republic is based on the principle of mandatory reporting. This form is sufficient for inspectors, going to the crash site to make further inquiries to be familiar with the situation. However, if we consider a wider engagement of event reporting, the mandatory reporting system should be modified due to information value. It would 
be very good to extend a description of an event or situation that preceded the event. This should be used mainly for the incidents. For aviation accidents there could be a situation where it would be impossible to meet this requirement due to fact that the circumstances are not known - accidents in remote terrain, no witnesses, etc.

Further it is appropriate to develop a proposal for a system of voluntary reporting, where the events would be reported anonymously. In current situation, because of the need to specify some personal information in the current system of mandatory reporting, some types of reports cannot be obtained. The result of a voluntary anonymous reporting system would be the fact that it would spread awareness about the potential hazards which someone met in the specific area of air operations, but would not be willing to share them under his name. This addition to the events database would be good for increasing the level of sharing safety information. This is one of the basic ideas of a properly functioning Safety Management System - it will reach the goal of the continuous improvement of safety.

In most companies introduction of a voluntary reporting system increased the number of reported events and thanks to it the process of creating corrective measures started to be more effective.

\section{CONCLUSION}

Current status of safety events reporting in the Czech Republic is based on a system of mandatory reporting. These messages have a prescribed structure and are reported by the rules about specific types of events. Due to the efforts to increase the safety it is necessary to extend a safety libraries and event databases about a larger number of less serious events, which in themselves do not pose a risk, but in some cases they are the trigger to the realization of an accident. About these events, we could learn thanks to implementation of a voluntary reporting system, which would be anonymous and therefore the announcer would not be threaten by any penalties.

\section{ACKNOWLEDGMENT}

This paper was supported by the Grant Agency of the Czech Technical University in Prague, grant No. SGS14/167/OHK2/2T/16.

\section{REFERENCES}

[1] ØIEN, K., I.B. UTNE a I.A. HERRERA. Building Safety indicators: Part 1 - Theoretical foundation. Safety Science. 2011, vol. 49, issue 2, p. 148-161. DOI: 10.1016/j.ssci.2010.05.012. available at: http://linkinghub.elsevier.com/retrieve/pii/S0925753510001335.

[2] ØIEN, K., I.B. UTNE, R.K. TINMANNSVIK a S. MASSAIU. Building Safety indicators: Part 2 - Application, practices and results. Safety Science. 2011, vol. 49, issue 2, s. 162-171. DOI: 10.1016/j.ssci.2010.05.015. Available at: http://linkinghub.elsevier.com/retrieve/pii/S0925753510001360

[3] AUTHORITY, Approved by the Secretary-General and published under his. Safety management manual (SMM). 2nd ed. Montréal, Québec: International Civil Aviation Organization, 2009. ISBN 978-929-2312954.

[4] L13. Letecký předpis o odborném zjištováni přičin leteckých nehod a incidentů. Czech Republic: Ministerstvo dopravy a spojů, 2013. Available at: http://lis.rlp.cz/predpisy/predpisy/dokumenty/L/L13/data/print/L13-cely.pdf

[5] European Union. Regulation of the European Parliament and of the Council (EU) No 376/2014 Occurrence reporting in civil aviation. In: Official Journal of the European Union L 167/23. 2003. Available at: http://eurlex.europa.eu/LexUriServ/LexUriServ.do?uri=OJ:L:2003:167:0023:003 6:EN:PDF

[6] European Union. Regulation of the European Parliament and of the Council (EU) No 42/2003 On the reporting, analysis and follow-up of occurrences in civil aviation, amending Regulation (EU) No 996/2010 of the European Parliament and of the Council and repealing Directive 2003/42/EC of the European Parliament and of the Council and Commission Regulations (EC) No 1321/2007 and (EC) No 1330/2007. In: Official Journal of the European Union L 122/18. 2014. Available at: http://eur-lex.europa.eu/legalcontent/EN/TXT/PDF/?uri=CELEX:32014R0376\&from=EN

[7] Czech Republic. Vyhláška, kterou se mění vyhláška Ministerstva dopravy a spojů č. 108/1997 Sb., kterou se provádí zákon č. 49/1997 Sb., o civilním letectví a o změně a doplnění zákona č. 455/1991 Sb., o živnostenském podnikání (živnostenský zákon), ve znění pozdějších předpisů, ve znění pozdějších předpisů. In: 359/2006. 2006. Dostupné z: http://www.mdcr.cz/NR/rdonlyres/4656F4C0-64A8-49F5-98F31FE8F8441139/0/vyhlaska_359_2006.pdf 